\title{
PERSONNEL SELECTION METHOD BASED ON TOPSIS MULTI-CRITERIA
} DECISION-MAKING METHOD ${ }^{1}$

\author{
Oya KORKMAZ²
}

\begin{abstract}
In this study, TOPSIS method, which is one of the multi-criteria decision making techniques, was used as a personal selection method in the logistics sector. This method was preferred in this study since it carries a set of superiorities. Twenty individuals applied for the vacant position to a logistics firm located in Mersin, Turkey and as a result of shortlisting process, only 9 candidates were qualified for interview by 6 human resource specialists and a regional director using 6 criteria. By means of the TOPSIS method, which was preferred as its application takes less time, is easy and as it gives better results, the 9 candidates were ranked and the most suitable candidate was recruited.
\end{abstract}

Keywords: Personnel Selection, Multi-criteria Decision Making, TOPSIS

JEL Classification: C44, C61, D22, D81, E24, M12

\section{TOPSIS ÇOK KRITERLI KARAR VERME TEKNIĞINE DAYALI PERSONEL SEÇIM YÖNTEMi}

\section{Öz}

Bu çalışmada lojistik sektöründe kişisel seçim yöntemi olarak çok kriterli karar verme tekniklerinden biri olan TOPSIS yöntemi kullanılmıştır. Bu yöntem bu çalışmada bir dizi üstünlük taşımasından dolayı tercih edilmiştir. Yirmi kişi boş pozisyon için Mersin' de bulunan bir lojistik firmasına başvurmuş ve ön değerlendirme sonucunda geriye kalan 9 aday 6 kriter, 6 insan kaynağı uzmanı ve bir bölge müdürü tarafından değerlendirmeye alınmıştır. Uygulamasının kısa, kolay ve daha iyi sonuç vermesi nedeniyle tercih edilen TOPSıS yöntemi sayesinde 9 adayın sıralaması yapılmış, en uygun aday işe alınmıştır.

Anahtar Kelimeler: Personel Seçimi, Çok Kriterli Karar Verme, TOPSIS

JEL Sınıflandırması: C44, C61, D22, D81, E24, M12

\footnotetext{
${ }^{1}$ This article was presented at the C-IASOS International Applied Social Sciences Conference that was held in DemreAntalya, Turkey on the dates of 19-21 April 2018 as a abstract.

${ }^{2}$ Doç. Dr.. Tarsus Üniversitesi, Uygulamalı Teknoloji ve Iş̧letmecilik Yüksekokulu, Uluslararası Ticaret ve Lojistik Bölümü, 33400, Mersin/Türkiye,: oyakorkmaz@mersin.edu.tr ORCID: 0000-0003-4570-803X
} 


\section{Introduction}

The global competition environment and technological developments have undermined the way the business world operates and led to serious developments in every sector. As a result of these changes, organizations have abandoned many traditional practices and have had to put new methods into practice in every field as required by competition. One of the fields where these new applications are deployed is the personnel selection methods which fall within the scope of human resources operations. The selection processes that have been carried out until now by being based on intuitive methods have presently started to be carried out in a more proper way with the sense of competition and the help of technology. These methods, which make a manager's work easier and yield positive outcomes for an organization, should be known by every manager and create awareness in them. The awareness will provide an outcome for the benefit of every organization.

In order to ensure that the investment made in the personnel is not wasted either during or after the selection process, in other words, in order for a company to gain advantage in terms of both time and cost, the personnel selection process must be carried out objectively. The intense competition in today's business world, in particular, and the developments in information technology, such as the Industry 4.0 and artificial intelligence, have brought about major changes in the business world. These changes have eliminated numerous job definitions and brought up new job definitions, the qualities required from the personnel have increased and as a result of all of these, the selection process has become more complicated. With also the help of technology, several methods have been developed for the selection process to be carried out in a more sound manner and shorter time under these circumstances. These are multi-criteria decision-making methods that cover several quantitative and non-quantitative criteria.

Multi-criteria decision-making techniques are modern methods that offer alternative selection methods to organizations to eliminate the problems that organizations experience when they use their current organization selection process and optimize numerous criteria that have been gathered while offering such alternatives (Urfalıoglu and Genç, 2013: 332). These methods are highly preferable by organizations as they cost less, are easy to apply, do not take much time and give reliable results. Additionally, these methods have been developed due to the failure of available methods in fully satisfying the needs, i.e. they were developed as a result of a need that has emerged (Şenel et al., 2017: 24).

The job definitions having become more complicated due to the effects of globalization, the developments in the internet and mobile technology, and the increase in the number of criteria sought from the labor force have been effective in the emergence of this need. These developments have revealed that the traditional personnel selection process can no longer be carried out in a healthy manner (Mutlu and Sarı, 2017: 192). Thus, at this point, multi-criteria decision-making techniques help managers because the multi-criteria decision-making techniques can evaluate several criteria, such as qualitative and quantitative criteria, in a shorter time and give more correct results. Additionally, the selection process carried out using these methods instills confidence in an organization. Today, most of the multi-criteria decision-making techniques are used in the personnel selection process due to these advantages of its. At the same time, the multi-criteria decision-making techniques form the manager's toolbox since the manager can pick up one or more from among these techniques which suit his/her own selection process.

As these methods allow selection through the use of the power of technology, they provide organizations with a set of skills such as speed, flexibility and problem-solving. Moreover, such methods also improve the innovative and creative capacity of organizations. Due to their superiorities mentioned above, these methods and similar methods will always exist for the purpose of selecting the right person for the right job as long as organizations exist. Additionally, these methods prevent the employees from bearing negative feelings towards their organization as such methods make the selection process fair and allow the recruitment of the right person for the right job. Thus, happy employees are created at the organization. The positive psychological impact 
created in the organization contributes to the efficiency of the organization. This study aims at creating awareness in this matter and increasing the rate of use of these methods. In other words, the aim of this study is to popularize the use of these methods (Aguado et al., 2016: 184).

\section{Personnel Selection}

Personnel selection involves a set of specialized processes that start with the need for personnel and end with the admission of the selected person to the organization (Coşgun, 2005: 419). Personnel selection at enterprises is the operation of selecting the person who would satisfy the requirements of the job in question to the greatest extent among the candidates who apply to an empty position. This selection process is highly troublesome and costly for businesses. Therefore, business plan and implement this selection process that will help selecting the suitable personnel for the job in a way that is effective and smooth (Aksakal and Dağdeviren, 2010: 905).

The right employee is the person who has the knowledge and skills necessitated by the job, is able to use the information and technology required by the job and is in harmony with the organization, the job and the employees. Failing to select the right personnel is a material and immaterial loss for the organization. In such a negative case, firing the personnel will be on the table. As new personnel will be employed in the place of the fired personnel, the organization will face unnecessary financial and time-related losses (Kenger and Organ, 2017: 166). Moreover, personnel turnover rate will increase as a result of not appointing the right personnel to the right position, and therefore, the costs in the process of selection will increase (Kabak and Kazançoğlu, 2012: 96).

It is occasionally observed that many successful managers, who have proven themselves in their respective fields, to fail as they were not able to select or work with the right personnel. The lack of information and awareness in the issue of applicability of the multi-criteria decision-making methods to the personnel selection process can be shown as the reason of such failure. Furthermore, some successful managers are still not aware that the personnel selection process requires the knowledge of separate field of specialization. Some of the successful managers still have serious lack of skills in this matter. Briefly, the personnel selection process requires a separate field of specialization. It is seen today that, still, many managers conceive personnel selection as a subject that they can overcome with their personal skills. Making the wrong choice means not only damaging one's own career, but also risking the future of the organization and condemning it to ambiguity (Erenel, 2012: 11-12). In addition to this, making the right choice increases not only the operational performance but also the organizational performance, while providing the organization with competitive advantage. Providing the organization with advantage in financial terms, this method will also ensure the return of investment. Proper application of the selection method either eliminates or minimizes the unfavorable effects (Ployhart et al., 2017: 295).

The decision-making process in the companies, particularly in those corporated, which have become aware of the advantages of the right selection methods, has turned into a complicated issue due to the collective evaluation of multiple factors and aims. Additionally, the decision-making function, which ceased to be of an individual nature and has gone beyond the manager due to the conflict of objectives in general, has become a process involving a group, team, and computerassisted for that matter. Organizations that use modern decision support systems gain a significant competitive advantage in the business environment that is increasingly becoming complicated (Eroğlu et al., 2014: 3). Also, these computer-assisted modular systems eliminate the problems encountered by the existing selection procedures, achieve reorganization of selection procedures and provide the human resources specialist with various alternative selection procedures (Lievens and Sackett, 2017: 58). In addition to all these, multi-criteria decision-making techniques have the quality to be compatible with all selection conditions based on the type of the problem (Khandekar and Chakraborty, 2016: 251). At the same time, the multi-criteria personnel selection methods have the advantage of choosing the best-match candidate for the skills required by the job (Karabašević et al., 2015: 43). 
Rapid changes are experienced in today's business world and the traditional selection methods fall behind these substantial changes. To overcome this, experts develop various innovative methods. By combining personal skills with the advantage of modern technology, these innovative methods provide the decision makers with new measurements and these methods are making their way into a wide range of use and applicability due to some of their advantages. In addition, these new innovative selection methods allow the enhancement of the image and increase the organizational attractiveness as they establish the perception of organizational fairness in an organization. At the same time, these methods prevent fraud and cheating, increase the level of reliability of various measurements and thus candidates with better qualifications are recruited (Ployhart et al., 2017: 297-298).

\section{Application of the multi-criteria decision-making methods to the personnel selection}

The leading factor is the human factor among the elements that play a role in the competitive advantage of the companies. For this reason, it is highly important to employ the right person for the right job and it is only possible with the effective selection methods to employ the right person for the right job. And the effective selection methods require a scientific way to approach the selection process. Basing on this awareness, the researchers completed their studies on this matter to make the organization managers become aware of the methods and benefits of the new generation personnel selection process. Eroğlu et al., (2014) applied to the personnel selection process the "ORESTE" method, one of the multi-criteria decision-making methods, and concluded the suitable personnel selection process according to various criteria (Eroğlu et al., 2014: 1). The personnel selection in companies, which has a major importance for the human resources, has become complicated due to its abstract and material characteristics inherent in human nature. Additionally, as the HR policies adopted by the companies for effective personnel recruitment are determined by being based on more than one criterion, the decision-making process has also become more complicated. For this reason, the researchers have conducted many studies to find a solution to the personnel selection process of the organizations using MCDM (Multi Criteria Decision Making) methods (Eroğlu et al., 2014: 10). One of these studies is the application of the MCDM method by Akın (2016) to the process of recruitment of a researcher at a public university. Akın (2016) completed the candidate ranking according to objective criteria by using fuzzy TOPSIS method, one of the MCDM methods (Akın, 2016: 224). As can be seen, the common objective of these studies is to find the right employee because the only element that makes successful organizations differ from others is the staff who are knowledgeable and have the qualities required by the job. For this reason, great care must be taken in the selection process. Basing on this idea, Kenger and Organ (2017) completed the selection of the most suitable personnel to be employed at a bank by using the Enthropy-based Aras Method, one of the MCMD methods (Kenger and Organ, 2017: 152). The personnel selection process by an organization forms the most important process that must be taken into consideration for an organization to survive and increase its market share in the globalizing world. Değermenci and Ayvaz (2016) who became aware of the importance of this process for the organizations applied the Fuzzy TOPSIS method to the personnel selection process for a specialist assistant position of an organization operating in the participation banking sector and selected the most suitable candidate for the job (Değermenci and Ayvaz, 2016, 77). Starting from the requirement that the selection of the most suitable candidate for the job be carried out professionally and systematically with minimum cost, maximum speed, highest efficiency and correctness, Şenel et al., (2017) found the most suitable candidate using the TOPSIS method among from the candidate pool of a leading firm operating in the automotive sector (Şenel et al., 2017: 19). Güngör et al., (2009) discussed the personnel selection process with the Fuzzy Analytical Hierarchy Process approach (Güngör et al., 2009: 641). In one of their studies they conducted for the personnel selection process that may affect the future performance and competitiveness of an organization, Göleç and Kahya (2007) set forth a comprehensive hierarchical structure. Göleç and Kahya (2007) used a competency-based fuzzy model in the process of matching an employee with a certain job (Göleç and Kahya, 2007: 143). These models are very important for a good quality human 
resource which is one of the key success factors of an organization because the complexity and the importance of the issue require analytical methods rather than intuitive decisions. Kelemenis and Askounis (2010) proposed a new TOPSIS-based multi-criteria approach in a study they conducted for this purpose and adapted this new approach to the problem of personnel selection (Kelemenis and Askounis, 2010: 4999). Aksakal and Dağdeviren (2010) discussed the personnel selection process for an international firm and developed an integrated algorithm for the solution of the problem by using DEMATEL (The Decision Making Trial and Evaluation Laboratory) and AAS (Analytical Network Process) together and determined and selected the most suitable candidate for the job (Aksakal and Dağdeviren, 2010: 905). Recent technological developments have brought about the accompanying issue of qualified personnel. For this reason, it has become a necessity to apply scientific approaches to the recruitment process of the candidates who will meet the expectations of the organizations. Basing on this idea, Akar and Çakır (2016) adopted the integrated Fuzzy AHP and MOORA approach in the recruitment process of logistics operation personnel for a firm operating in the logistics sector and, by ranking the candidates of logistics operation personnel, they proposed the most suitable candidate for the job (Akar and Çakır, 2016: 185). Basing on these studies, Adıgüzel (2009), who stated that the issue of suitable personnel selection is actually a multi-criteria decision-making problem, has shown in a model study that the Analytical Hierarchy Process (AHP), which is one of the multi-criteria decision-making methods, can be used in the personnel selection process (Adıgüzel, 2009: 243). For the same purpose, Ulutaş et al., (2018) have, in a study they conducted, used the Fuzzy Analytical Hierarchy Process (FAHP) and Fuzzy Gray Relational Analysis (FGRA) methods together and performed the selection process of personnel in a factory that manufactures electrical components for cars (Ulutaş et al., 2018: 223). The selection of the right personnel has always been a major issue for the organizations. With the globalizing world, developing technologies and increasing specialization especially in the present day, the HR managers prove to be inadequate in choosing the right personnel. In particular, the decisions on the selection of the right personnel in the business areas where also the human life is concerned have become more important and critical. One of the most important problems encountered during the selection of personnel is the existence of decisions that include personal judgments. When the studies in the literature are reviewed, the success of the MOORA method in making the right decision is noteworthy. For this reason, Çelikbilek (2018) proposed an integrated gray AHP-MOORA approach for personnel selection. The reason the gray numbers are preferred is their ability to represent personal judgments and minimize bias resulting from personal judgments during selections. For this purpose, Çelikbilek (2018) carried out an application on the selection of managers in the health sector by using the integrated gray AHP-MOORA approach and verified the results by comparing them with different methods (Çelikbilek, 2018: 69-82). Today, organizations are aware of the choice of staff in such a manner as to create added value for them. For this reason, organizations are questioning the efficiency of the existing recruitment processes much more in order to attract the workforce that will create added value. For this reason, they want to contribute to efficiency and effectiveness by experimenting with different recruitment methods (Akkaya, 2010: 1). For this purpose, Akkaya (2010) adapted the Analytical Hierarchy Method (AHM), which is one of the various recruitment methods, to the problem of "selection of a production and planning engineer" for a firm operating in the food sector and determined the most suitable candidate for the job based on the job descriptions prepared as a result of the work analyses (Akkaya, 2010: 9). Personnel selection is an important issue for organizations and requires uncertain data in the process of decision making. For this reason, Dağdeviren (2007) proposed an algorithm for solving the problem of personnel selection by using the Fuzzy Analytical Hierarchy Process (FAHP) method. The proposed algorithm was used to determine the personnel to be promoted in an organization and the candidates were ranked in the order of priority (Dağdeviren, 2007: 791). It is seen that the most important asset of the organizations is human resources in today's management approach. For this reason, the selection processes are required to be completed in a proper and informed manner. In fact, the selection and placement stage is basically a decision-making process. Based on this idea, İçigen and Çetin (2018) applied the pre-selection process for accommodation establishments with 
the AHP-Based TOPSIS method (İçigen and Çetin, 2018: 179). In a study they conducted, Köse et al., (2013) solved the problem of personnel selection for an organization providing training services by using the GRA and GAN methods together. The results obtained show that Gray Relational Analysis (GRA) can be applied successfully in the solution stage of personnel selection problems (Köse et al., 2013: 461). Different jobs and positions in the body of organizations require different knowledge, skills and personal traits. For this reason, there are many criteria that the organizations must take into account during the personnel selection process. The problems related to this selection can only be solved by the Multi-Criteria Decision-Making (MCDM) methods proposed in the literature. Based on this idea, Adalı (2016) solved this problem by adapting the EVAMIX (Evaluation of Mixed Data) and IMCRM (Iterative Multi Criteria Decision Making) methods to the nurse selection problem of a private hospital (Adalı, 2016: 69). The degree of mutual dependence of the criteria in the personnel selection constitutes an important element in the decision-making process. For this reason, the selection process must be considered with a multi-perspective approach and care must be shown in its application. Basing on this consideration, Yıldız and Aksoy (2015) allowed for the selection of the most suitable personnel by using the Analytical Hierarchy Process method at a firm operating in the automotive sub-industry which planned to recruit personnel for more than one unit. Yıldız and Aksoy (2015) also demonstrated that Analytical Hierarchy Process can be used as an effective method in personnel selection process (Yıldız and Aksoy, 2015: 59). Ünal (2011) showed that the same method also applied to the personnel selection process in different sectors by giving examples from previous studies and established that it was useful to use this method in personnel selection process (Ünal, 2011: 18). The selection of personnel with a multi-criteria decision-making method significantly affects the future character and performance of the firm. In addition, these methods reduce subjectivity as much as possible, solve the administrative problems and provide maximum benefit from the available manpower of an organization. Because of this advantage of multi-criteria decision-making methods, Bogdanovic and Miletic (2014) applied an integrated approach to multi-criteria decision making techniques, including AHP and PROMETHEE, to the department of a Serbian firm consisting of five employers which had to be reorganized with the reduction of three employees. Bogdanovic and Miletic (2015) have chosen with this method the most suitable personnel from the manpower available in an organization which was in the process of reorganization and reduction (Bogdanovic and Miletic, 2014: 22). Multi-criteria decisionmaking methods are positive methods that have the advantage of ignoring the fuzziness of managers' decisions. One of these methods which is effective in solving the problems of personal selection is the ELECTRE method. Afshari et al., (2010) have applied the ELECTRE method to the selection process of 5 personnel who applied to a telecommunication firm in Iran and determined the most suitable candidate for the job (Afshari et al., 2010: 3068).

It was noted that the application of multi-criteria decision-making methods in the personnel selection process yielded to the organizations many favorable results such as speed, increase in efficiency and cost advantage. In this study inspired by this information, the TOPSIS method was decided to be used among multiple-criteria decision-making methods, because its application and interpretation are easy and because it gives consistent results.

\section{Methodology}

The analysis on personnel selection in the logistics sector was conducted with the method of TOPSIS. With this method, the personnel to be employed in the logistics sector were ranked.

\subsection{TOPSIS Method}

The TOPSIS method was developed as a multi-criteria decision-making technique by Hwang and Yoon (1981). Hwang and Yoon developed the TOPSIS method based on the greatest distance to the positive-ideal and negative-ideal solutions. This method consists of 6 steps. These are applied based on the following order (Supçiller and Çapraz, 2011: 9):

Step 1: Forming the Decision Matrix 
The rows of the decision matrix contain the decision points that are aimed to be ranked, while its columns contain the assessment factors to be used in making a decision. The matrix A formed by the decision-maker is defined as the evaluation matrix and shown below (Uygurtürk and Korkmaz, 2012: 95-115):

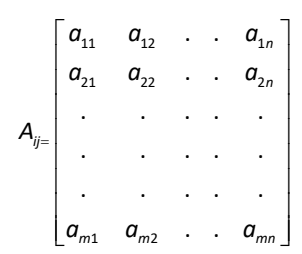

In the matrix Aij, $\mathrm{m}$ is the number of decision points and $\mathrm{n}$ is the number of evaluation factors.

\section{Step 2: Forming the Normalized Decision Matrix (R)}

The decision matrix is normalized by dividing all values in the matrix by the square root of the summed squares of the values in the column that these values are. The following formula is used for the process of normalization (Ömürbek et al., 2013: 125).

$$
r_{i j}=\frac{a_{i j}}{\sqrt{\sum_{i=1}^{m} a_{i j}^{2}}} \quad i=1, \ldots . ., m \quad j=1, \ldots . ., n
$$

The standard decision matrix $\mathrm{R}$ is shown as below:

$$
R_{i j=}\left[\begin{array}{ccccc}
r_{11} & r_{12} & \cdot & \cdot & r_{1 n} \\
r_{21} & r_{22} & \cdot & \cdot & r_{2 n} \\
\cdot & \cdot & \cdot & \cdot & \cdot \\
\cdot & \cdot & \cdot & \cdot & \cdot \\
\cdot & \cdot & \cdot & \cdot & \cdot \\
r_{m 1} & r_{m 2} & \cdot & \cdot & r_{m n}
\end{array}\right]
$$

\section{Step 3: Forming the Weighted Standard Decision Matrix (V)}

Firstly, the weight values in relation to the evaluation factors (wj) are determined.

$$
\left(\sum_{j=1}^{n} w_{j}=1\right)
$$

Then, the elements in each column of the matrix $\mathrm{R}$ are multiplied by the corresponding value $\mathrm{w}_{\mathrm{j}}$, and the matrix $\mathrm{V}$ is formed. This matrix $\mathrm{V}$ is shown below (Dumanoğlu and Ergül, 2010: 106).

$$
V_{i j}=\left[\begin{array}{ccccc}
w_{1} r_{11} & w_{2} r_{12} & \cdot & \cdot & w_{n} r_{1 n} \\
w_{1} r_{21} & w_{2} r_{22} & \cdot & \cdot & w_{n} r_{2 n} \\
\cdot & \cdot & \cdot & \cdot & \cdot \\
\cdot & \cdot & \cdot & \cdot & \cdot \\
\cdot & \cdot & \cdot & \cdot & \cdot \\
w_{1} r_{m 1} & w_{2} r_{m 2} & \cdot & \cdot & w_{n} r_{m n}
\end{array}\right]
$$

\section{Step 4: Finding the Ideal $\left(A^{+}\right)$and Negative Ideal $\left(A^{-}\right)$Solutions}

The TOPSIS method assumes that each evaluation criterion has a monotonous increasing or decreasing trend. At this stage, determining the maximum and minimum solution points involves 
determining and taking the maximum and minimum values among the elements of each column in the matrix obtained in Step 3. Based on the weighted normal values at this stage, positive ideal solution $\left(A^{+}\right)$and negative ideal solution $\left(A^{-}\right)$values are found. $A^{+}$and $A^{-}$are defined in terms of weighted normalized values. Thus, the maximum and minimum values of each column are defined (Özçelik and Kandemir, 2015: 105-106).

$$
\begin{array}{ll}
A^{+}=\left\{v_{1}^{+}, v_{2}^{+}, \ldots ., v_{n}^{+}\right\} & \text {(maximum values) } \\
A^{-}=\left\{v_{1}^{-}, v_{2}^{-}, \ldots ., v_{n}^{-}\right\} & \text {(minimum values) }
\end{array}
$$

\section{Step 5: Calculating the Distances between Alternatives}

In the 5th step, after defining the ideal points, the values of distance to the maximum and minimum ideal points are calculated based on the following formula (Uygurtürk and Korkmaz, 2012: 104-105)

$$
\begin{aligned}
& S_{i}^{+}=\sqrt{\sum_{j=1}^{n}\left(v_{i j}-v_{j}^{+}\right)^{2}} \quad i=1,2, \ldots . ., m \\
& S_{i}^{-}=\sqrt{\sum_{j=1}^{n}\left(v_{i j}-v_{j}^{-}\right)^{2}} \quad i=1,2, \ldots \ldots ., m
\end{aligned}
$$

The numbers of $S_{i}^{+}$and $S_{i}^{-}$to be calculated here are as high as the number of decision points.

\section{Step 6: Calculating The Relative Proximity to The Ideal Solution}

The criteria of ideal and negative ideal discrimination are utilized in the calculation of the relative proximity of each alternative to the ideal solution $\left(C_{i}^{*}\right)$. The criterion that is used here is the share of the negative ideal discrimination criterion in the total discrimination criterion. The relative proximity to the ideal solution is calculated as follows:

$C_{i}^{*}=\frac{S_{i}^{-}}{S_{i}^{-}+S_{i}^{+}}, \quad 0 \leq C_{i}^{*} \leq 1 ; \quad i=1,2, \ldots \ldots \ldots, m$

According to this formula, as the distance from the negative ideal solution increases, the proximity to the ideal solution is higher. Accordingly, increased ideal discrimination value of the alternative in question means a decrease in the proximity to the ideal solution. In the same way, increased negative ideal discrimination means an increase in the proximity to the ideal solution. In the last step, ranking is achieved by looking at the relative proximity values that have been formed for each alternative. Hence, it is concluded that the alternative that is the closest to the ideal solution among the alternative, that is, the alternative with the greatest value of $C_{i}^{*}$ is the best alternative. Alternatives are ranked based on priority by ranking $C_{i}^{*}$ values in a descending order (Uzun and Kazan, 2016: 102-103).

\subsection{Logistics Operation Personnel Selection}

The developments in transportation and communication, the increase in the volume of global trade and e-trade, the introduction of new products and services have led to a rapid growth in the logistics sector. In addition, the inclination of the organizations to outsourcing in the operations that fall beyond the scope of their basic capabilities has contributed to this growth. However, the growth of the sector has brought with it the problem of qualified personnel. Logistics companies employ innovative, analytical, experienced and qualified individuals who can provide quality and differentiation in their training. Therefore, it is inevitable to use scientific approaches in the recruitment process of candidates who can meet the expectations of organizations in this sector (Akar and Çakır, 2016: 185).

In this study, the personnel selection, which is extremely important for corporate logistics firms, was carried out using the TOPSIS method being one of the multi-criteria decision-making methods. 
The reason for using this method is that it allows the personnel selection to be carried out in an easier and faster way (Yıldız and Aksoy, 2015: 61).

In this study, 20 candidates applied for work in the position of domestic logistics operation personnel for a firm in Mersin operating in the logistics sector, 11 of these candidates were disqualified as they could not provide the requisites and only 9 candidates satisfying the criteria were evaluated.

The weighted data created according to the criteria sought from the candidates were obtained through interviews made by a total of 7 staff members consisting of a regional director and the employees of human resources department.

The firm listed as follows the qualities sought from the logistics operation personnel that it intended to employ:

- Experience in logistics

- Education/Training

- Flexible work hours and overtime work

- Proficiency in MS Office Programs

- Package software used in the logistics field (ERP, SAP vs.)

- Recommendation letters

The schematic structure showing the visual expression of qualities sought from each candidate is provided in Figure 1.

Figure 1: The Hierarchical Structure of The Selection Process

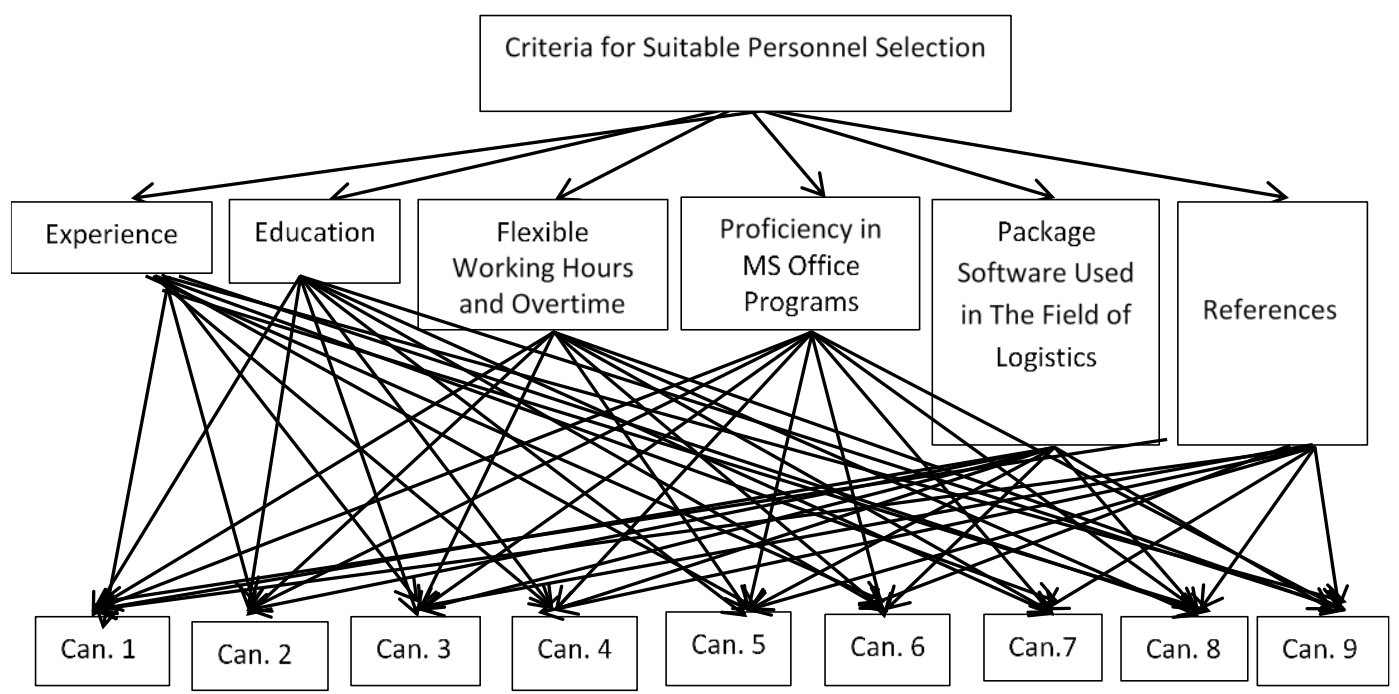

\subsection{Findings}

The data obtained according to 6 criteria sought from 9 candidates, who were discussed within the scope of analysis, were used in the ranking of the candidates. The ranking based on the TOPSIS method includes the following steps: 


\section{Step 1: Forming The Decision Matrix (A)}

The rows of the decision matrix included the candidates whose advantages were aimed to be ranked, and the columns included the criteria for assessment to be used. The study included 9 decision points (number of candidates) and 6 assessment factors (qualities/criteria wanted from the candidates). At the first stage, a 9x6 Standard Decision Matrix was formed for the TOPSIS method. This matrix is shown in Table 1. While forming the decision matrix, firstly TOPSIS number equivalent was assigned to qualitative criteria, which each candidate had, in line with co-decision of the regional manager and human resources unit. While assigning numerical equivalents to qualitative statements, namely carrying out weighting, the mentioned team evaluated the qualifications of candidates from 1 to 10 .

Table 1: The Decision Matrix for The Selection Criteria (A)

\begin{tabular}{|c|c|c|c|c|c|c|}
\hline \multirow[b]{2}{*}{ Candidates } & \multicolumn{5}{|c|}{ Criteria } & \multirow[b]{2}{*}{$\begin{array}{l}\quad 6 \\
\text { Recommenda- } \\
\text { tion } \\
\text { Letters }\end{array}$} \\
\hline & $\begin{array}{l}1 \\
1 \\
\text { Logistics } \\
\text { Experience }\end{array}$ & $\begin{array}{c}2 \\
\text { Education }\end{array}$ & \begin{tabular}{l}
\multicolumn{1}{c}{3} \\
Flexible \\
Working \\
Hours and \\
Overtime \\
\end{tabular} & $\begin{array}{l}\quad 4 \\
\text { Proficiency } \\
\text { in MS Office } \\
\text { Programs }\end{array}$ & \begin{tabular}{l}
\multicolumn{1}{c}{5} \\
Package \\
Software Used \\
in The Field of \\
Logistics
\end{tabular} & \\
\hline Can. 1 & 4 & 8 & 5 & 6 & 7 & 1 \\
\hline Can. 2 & 3 & 8 & 8 & 5 & 1 & 1 \\
\hline Can. 3 & 3 & 6 & 8 & 7 & 1 & 8 \\
\hline Can. 4 & 4 & 1 & 10 & 6 & 1 & 8 \\
\hline Can. 5 & 9 & 5 & 3 & 6 & 5 & 1 \\
\hline Can. 6 & 4 & 10 & 10 & 7 & 8 & 8 \\
\hline Can. 7 & 3 & 10 & 6 & 7 & 1 & 1 \\
\hline Can. 8 & 3 & 7 & 6 & 8 & 5 & 1 \\
\hline Can. 9 & 3 & 10 & 8 & 8 & 6 & 5 \\
\hline
\end{tabular}

\section{Step 2: Forming The Normalized Decision Matrix (R)}

The normalized decision matrix in Table 2 was calculated by utilizing the elements in the matrix A shown in Table 1 and using equation (1)

Table 2: The Normalized Decision Matrix of The Selection Criteria (R)

\begin{tabular}{|c|c|c|c|c|c|c|}
\hline & & & Criteria & & & \\
\hline \multirow[t]{3}{*}{ Candidates } & $\begin{array}{c}1 \\
\text { Logistics }\end{array}$ & $\begin{array}{c}2 \\
\text { Education/ }\end{array}$ & $\begin{array}{c}3 \\
\text { Flexible }\end{array}$ & $\begin{array}{l}4 \text { Profi- } \\
\text { ciency }\end{array}$ & $\begin{array}{c}5 \\
\text { Packaged }\end{array}$ & $\begin{array}{l}6 \text { Recom- } \\
\text { mendation }\end{array}$ \\
\hline & Experience & Training & Working & in MS Office & Software & Letters \\
\hline & & & $\begin{array}{l}\text { Hours and } \\
\text { Overtime }\end{array}$ & & $\begin{array}{l}\text { Used } \\
\text { in the Field of } \\
\text { Logistics }\end{array}$ & \\
\hline Can. 1 & 0.303239 & 0.344584 & 0.224055 & 0.297044 & 0.491304 & 0.067116 \\
\hline Can. 2 & 0.227429 & 0.344584 & 0.358489 & 0.247537 & 0.070186 & 0.067116 \\
\hline Can. 3 & 0.227429 & 0.258438 & 0.358489 & 0.346552 & 0.070186 & 0.536925 \\
\hline Can. 4 & 0.303239 & 0.043073 & 0.448111 & 0.297044 & 0.070186 & 0.536925 \\
\hline Can. 5 & 0.682288 & 0.215365 & 0.134433 & 0.297044 & 0.350931 & 0.067116 \\
\hline Can. 6 & 0.303239 & 0.43073 & 0.448111 & 0.346552 & 0.56149 & 0.536925 \\
\hline Can. 7 & 0.227429 & 0.43073 & 0.268866 & 0.346552 & 0.070186 & 0.067116 \\
\hline Can. 8 & 0.227429 & 0.301511 & 0.268866 & 0.396059 & 0.350931 & 0.067116 \\
\hline Can. 9 & 0.227429 & 0.43073 & 0.358489 & 0.396059 & 0.421117 & 0.335578 \\
\hline $\begin{array}{l}\text { Weights } \\
\left(w_{j}\right)\end{array}$ & 0.166667 & 0.166667 & 0.166667 & 0.166667 & 0.166667 & 0.166667 \\
\hline
\end{tabular}

Step 3: Forming The Weighted Standard Decision Matrix (V) 
The weight degrees corresponding to the evaluation factors were calculated before proceeding to Step 3 of the TOPSIS method. To do this, the human resources specialists and the regional director of the firm held a meeting and decided that the criteria sought from the candidates be used in the analysis with equal weight. The normalized values calculated in the previous step were multiplied by $w_{j}$ values and the weighted normalized values were found. These values are shown in Table 3.

Table 3: Forming The Weighted Standard Decision Matrix for The Selection Criteria (V)

\begin{tabular}{|c|c|c|c|c|c|c|}
\hline \multirow{3}{*}{ Candidates } & \multicolumn{5}{|c|}{ Criteria } & \multirow{3}{*}{$\begin{array}{l}\quad 6 \text { Recom- } \\
\text { mendation } \\
\text { Letters }\end{array}$} \\
\hline & $\begin{array}{c}1 \\
\text { Logistics }\end{array}$ & $\begin{array}{c}2 \\
\text { Education/ }\end{array}$ & $\begin{array}{c}3 \\
\text { Flexible }\end{array}$ & $\begin{array}{l}4 \text { Profi- } \\
\text { ciency }\end{array}$ & $\begin{array}{c}5 \\
\text { Packaged }\end{array}$ & \\
\hline & Experience & Training & $\begin{array}{l}\text { Working } \\
\text { Hours and } \\
\text { Overtime }\end{array}$ & $\begin{array}{l}\text { in MS Office } \\
\text { Programs }\end{array}$ & $\begin{array}{l}\text { Software } \\
\text { Used } \\
\text { in the Field of } \\
\text { Logistics }\end{array}$ & \\
\hline Can. 1 & 0.05054 & 0.057431 & 0.037343 & 0.049507 & 0.081884 & 0.011186 \\
\hline Can. 2 & 0.037905 & 0.057431 & 0.059748 & 0.041256 & 0.011698 & 0.011186 \\
\hline Can. 3 & 0.037905 & 0.043073 & 0.059748 & 0.057759 & 0.011698 & 0.089487 \\
\hline Can. 4 & 0.05054 & 0.007179 & 0.074685 & 0.049507 & 0.011698 & 0.089487 \\
\hline Can. 5 & 0.113715 & 0.035894 & 0.022406 & 0.049507 & 0.058489 & 0.011186 \\
\hline Can. 6 & 0.05054 & 0.071788 & 0.074685 & 0.057759 & 0.093582 & 0.089487 \\
\hline Can. 7 & 0.037905 & 0.071788 & 0.044811 & 0.057759 & 0.011698 & 0.011186 \\
\hline Can. 8 & 0.037905 & 0.050252 & 0.044811 & 0.06601 & 0.058489 & 0.011186 \\
\hline Can. 9 & 0.037905 & 0.071788 & 0.059748 & 0.06601 & 0.070186 & 0.05593 \\
\hline
\end{tabular}

\section{Step 4: Finding The Ideal $\left(A^{+}\right)$and Negative Ideal $\left(A^{-}\right)$Solutions}

At this stage, the ideal $A^{+}$and negative ideal $A^{-}$solution sets are created. For the set $A^{+}$, the highest values in all the columns of the matrix $V$ and for the set $A^{-}$, the lowest values in these columns were taken, and the following sets were created.

Table 4: Finding The Ideal $\left(\mathbf{A}^{+}\right)$and Negative Ideal $\left(\mathbf{A}^{-}\right)$Solutions for The Selection Criteria

\begin{tabular}{lllllll}
\hline $\mathbf{A}^{+}$ & 0.113715 & 0.071788 & 0.074685 & 0.06601 & 0.093582 & 0.089487 \\
$\mathbf{A}^{-}$ & 0.037905 & 0.007179 & 0.022406 & 0.041256 & 0.011698 & 0.011186 \\
\hline
\end{tabular}

\section{Step 5: Calculating The Distance between Alternatives}

At this stage, the distance of each alternative to the positive ideal solution was calculated by equation (2), while the distance of each alternative to the negative ideal solution was calculated by equation (3). The calculated values are shown in Table 5.

Table 5: Calculating The Distance between Alternatives

\begin{tabular}{lll}
\hline Candidates & \multicolumn{1}{c}{ S $^{+}$} & \multicolumn{1}{c}{ S$^{-}$} \\
\hline Can. 1 & 0.110145 & 0.088894 \\
Can. 2 & 0.14009 & 0.062608 \\
Can. 3 & 0.116481 & 0.095322 \\
Can. 4 & 0.123056 & 0.095352 \\
Can. 5 & 0.107965 & 0.093964 \\
Can. 6 & 0.063711 & 0.142041 \\
Can. 7 & 0.139799 & 0.070347 \\
Can. 8 & 0.120275 & 0.071829 \\
Can. 9 & 0.087428 & 0.107724 \\
\hline
\end{tabular}

Step 6: Calculating The Relative Proximity to The Ideal Solution 
The relative proximity of each decision point to the ideal solution (C) was calculated by equation 4. The values that were calculated by equation 4 are presented in Table 6.

Table 6: Calculating The Relative Proximity to The Ideal Solution

\begin{tabular}{ll}
\hline Candidates & \multicolumn{1}{c}{ C } \\
\hline Can. 1 & 0.446616 \\
Can. 2 & 0.308872 \\
Can. 3 & 0.45005 \\
Can. 4 & 0.436578 \\
Can. 5 & 0.46533 \\
Can. 6 & 0.690349 \\
Can. 7 & 0.334754 \\
Can. 8 & 0.373907 \\
Can. 9 & 0.552 \\
\hline
\end{tabular}

According to these results, the ranking priority is given to the candidate with the highest $C$ value. Accordingly, the " $C$ " values of the candidates in the study and their ranking are given in Table 7.

Table 7: “C” Values and Ranking

\begin{tabular}{lll}
\hline Candidates & \multicolumn{1}{c}{ C } & Rank \\
& values & \\
\hline Can. 6 & 0.690349 & 1 \\
Can. 9 & 0.552 & 2 \\
Can. 5 & 0.46533 & 3 \\
Can. 3 & 0.45005 & 4 \\
Can. 1 & 0.446616 & 5 \\
Can. 4 & 0.436578 & 6 \\
Can. 8 & 0.373907 & 7 \\
Can. 7 & 0.334754 & 8 \\
Can. 2 & 0.308872 & 9 \\
\hline
\end{tabular}

According to the result obtained from Table 7, it is seen that the most suitable candidate for the qualification required by the job is candidate 6 and this candidate is the person who should be ranked first in the order of preference for recruitment. Whereas, candidate 2 is the candidate who meets the required conditions at the minimum level and therefore should be ranked last in the order of preference.

\section{Conclusion and Recommendation}

This study investigated the applicability of the multi-criteria decision method of TOPSIS (Technique for Order of Preference by Similarity to Ideal Solution) to the personnel selection process. For this purpose, a process of personnel selection was carried out at a corporate firm in the logistics sector. A total of 20 candidates applied for the vacant position opened by the firm. The selection ranking of 9 candidates that were evaluated after the result of prequalification was performed according to the TOPSIS method.

As the result of ranking, it was recommended that the order of preference for recruitment be as follows: Candidate 6 first, Candidate 9 second, Candidate 5 third, Candidate 3 fourth, Candidate 1 fifth, Candidate 4 sixth, Candidate 8 seventh, Candidate 7 eighth and Candidate 2 ninth. 
As the TOPSIS method is a decision making technique by a group, the criteria and weights used in the selection process of this study were determined by 6 human resource specialists and a regional director. As the result of the ranking, candidate 6 , who ranked first, was employed. Furthermore, it was determined that the personal evaluations of the 6 human resources specialists and the regional manager were also in line with this selection. This shows how consistent results this method yields. However, in order to carry out these applications, the organizations that intend to carry out this application should have had some qualities. For this reason, a corporate firm with an understanding and capacity to apply this method has been selected in our study. This is a logistics firm that provides international transportation services with a large number of employees. This organization, which has the mentioned qualities, i.e. this firm which is a corporate firm with a large number of employees, meets the requirements for the cited applications. Thanks to this method, the firm has become one of the leading companies in the sector. In this firm, which has become aware of the human resources and which indicates that it has dedicated itself to human resources, the recruitment process was concluded on the basis of the requirements of the job. The performance, satisfaction, loyalty and motivation of the personnel, who were recruited based on the requirements of the job, have increased and the level of stress and the frequency of work accidents have decreased. At the same time, the physical and mental health of the employee were protected. In other words, As a result of wrong selection a candidate may be placed in a job that requires more skills than he/she has. Consequently, the person will undergo stress for failing to do their job well. As a result of stress, an employee may lose his mental and physical health. Whereas, a right choice creates a positive atmosphere in an organization. This positive atmosphere positively affects several parameters such as the organization's performance, efficiency, staff turnover rate, absenteeism and work accidents.

Hence, this study emphasizes the applicability of multi-criteria decision-making techniques (TOPSIS, AHP, etc.) in all selection methods and all sectors, especially in personnel selection. In particular, it is seen that these methods provide the decision makers with more convenience and time-saving than the traditional selection methods in cases where there are more criteria involved. In addition, due to the more spot-on selection by using these methods, the decision-maker shows less effort and spends less time in the selection process. In addition these methods provide more cost advantage to the organization.

Some difficulties were encountered in the present study, which we carried out in order to point out the benefits provided by the methods mentioned above to the organization, the manager and the employee. The low number of organizations that apply the multi-criteria decision-making technique to the selection processes and the refusal of these organizations to participate in the study are the main challenges.

In addition, developments in the socio-cultural and mass media will change the quality and quantity to be sought in personnel selection. For this reason, the researchers are recommended to use this method and its advanced versions in their future studies in order not to waste the funds of the organization and the efforts spent in the selection processes. Because the quality and quantity of personnel will totally change in the future, the use of these methods in personnel selection processes will become an obligation rather than a requirement. In addition, in this study, the researchers are recommended for their future studies to use these methods not only in personnel selection processes, but also in all decision-making processes.

\section{References}

Adalı Aytaç, Esra (2016). EVAMIX ve TODIM Yöntemleri İle Sağlık Sektöründe Personel Seçimi. Alphanumeric Journal, 4(2), 69-84.

Adıgüzel, Orhan (2009). Personel Seçiminin Analitik Hiyerarşisi Prosesi Yöntemiyle Gerçekleştirilmesi. Dumlupınar Üniversitesi Sosyal Bilimler Dergisi, 24, 243-252. 
Afshari, A.R., Mojahed, M., Yusuff, R.M., Hong, T.S. and Ismail, M.Y. (2010). Personel Selection Using ELECTRE. Journal of Applied Sciences, 10, 3068-3075.

Aguado, D., Rico, R., Rubio J. V. and Fernández, L. (2016). Applicant Reactions to Social Network Web Use in Personnel Selection and Assessment. Journal of Work and Organizational Psychology, 32, 183-190.

Akar, G. S. and Çakır, E. (2016). Lojistik Sektöründe Bütünleştirilmiş Bulanık AHP - MOORA Yaklaşımı ile Personel Seçimi. Yönetim ve Ekonomi Araştırmaları Dergisi, 14(2), 185-199.

Akın, Nalan Gülten (2016). Personel Seçiminde Çok Kriterli Karar Verme: Bulanık Topsis Uygulaması. İşletme Araştırmaları Dergisi, 8/2, 224-254.

Akkaya, Gökay (2010). Analitik Hiyerarşi Yöntemi İle Personel Seçimi ve Bir Uygulama. Verimlilik Dergisi, 4, 1-16.

Aksakal, E. and Dağdeviren, M. (2010). ANP ve DEMATEL Yöntemleri ile Personel Seçimi Problemine Bütünleşik Bir Yaklaşım. Gazi Üniv. Müh. Mim. Fak. Der., 25(4), 905-913.

Bogdanovic, Dejan and Miletic, Slavica (2014). Personnel Evaluation and Selection by Multicriteria Decision Making Method. Economic Computation \& Economic Cybernetics Studies \& Research, 48(3), 22-39.

Coşgun, E. (2005). Teknik Personel Seçiminde Bir Uzman Sistem Modeli. Mühendislik Bilimleri Dergisi, 11(3), 417-423.

Çelikbilek, Yakup (2018). Using An Integrated Grey AHP-MOORA Approach for Personnel Selection: An Application on Manager Selection in The Health Industry. Alphanumeric Journal, 6(1), 69-82.

Dağdeviren, Metin (2007). Bulanık Analitik Hiyerarşi Prosesi İle Personel Seçimi ve Bir Uygulama. Gazi Üniversitesi Mühendislik Mimarlık Fakültesi Dergisi, 22(4), 791-799.

Değermenci, Aleyna and Ayvaz, Berk (2016). Bulanık Ortamda Topsis Yöntemi İle Personel Seçimi: Katılım Bankacılığı Sektöründe Bir Uygulama. İstanbul Ticaret Üniversitesi Fen Bilimleri Dergisi, 15(30), 77-93.

Dumanoğlu, S. and Ergül, N. (2010). IMKB'de İşlem Gören Teknoloji Şirketlerinin Mali Performans Ölçümü. Muhasebe ve Finansman Dergisi, 48, 101-111.

Erenel, Fahri (2012). Personel Temin ve Seçim Sürecinde Adaylarda Oluşan Adalet Algısının Örgüte Etkilerinin Analizi. Maliye Finans Yazıları, 95, 9-21.

Eroğlu, E., Yıldırım, F. B. and Özdemir, M. (2014). Çok Kriterli Karar Vermede “Oreste” Yöntemi ve Personel Seçiminde Uygulanması. İstanbul Üniversitesi Işletme Fakültesi Işletme iktisadı Enstitüsü Yönetim Dergisi, 25(76), 1-19.

Göleç, Adem and Kahya, Esra (2007). A Fuzzy Model for Competency-Based Employee Evaluation And Selection. Computers \& Industrial Engineering, 52(1), 143-161.

Güngör, Zülal, Serhadlıoğlu, Gürkan and Kesen, Saadettin Erhan (2009). A Fuzzy AHP Approach to Personnel Selection Problem. Applied Soft Computing, 9(2), 641-646.

İçigen Tarcan, Ebru and Çetin İpekçi, Emre (2018). AHP Temelli TOPSIS Yöntemi İle Konaklama İşletmelerinde Personel Seçimi. Balkan Sosyal Bilimler Dergisi, 7(13), 179-187.

Kabak, M. and Kazançoğlu, Y. (2012). Bulanık Analitik Hiyerarşi Yöntemiyle Öğretmen Seçimi ve Bir Uygulama. Afyon Kocatepe Üniversitesi, iiBF Dergisi, 16(1), 95-111.

Karabašević, D., Stanujkić, D. and Urošević, S. (2015). The MCDM Model for Personnel Selection Based on SWARA and ARAS Methods. Management, 77, 43-52. 
Kelemenis, Alecos and Askounis, Dimitrios (2010). A New TOPSIS-Based Multi-Criteria Approach to Personnel Selection. Expert Systems with Applications, 37(7), 4999-5008.

Kenger, M. D. and Organ, A. (2017). Banka Personel Seçiminin Çok Kriterli Karar Verme Yöntemlerinden Entropi Temelli Aras Yöntemi ile Değerlendirilmesi. Adnan Menderes Üniversitesi, Sosyal Bilimler Enstitüsü Dergisi, 4(4), 152-170.

Khandekar, V. A. and Chakraborty, S. (2016). Personnel Selection Using Fuzzy Axiomatic Design Principles. Business: Theory and Practice, 17(3), 251-260.

Köse, Erkan, Aplak, Hakan Soner and Kabak, Mehmet (2013). Personel Seçimi için Gri Sistem Teori Tabanlı Bütünleşik Bir Yaklaşım. Ege Akademik Bakış, 13(4), 461-471.

Lievens, F. and Sackett, R. P. (2017). The Effects of Predictor Method Factors on Selection Outcomes: A Modular Approach to Personnel Selection Procedures. Journal of Applied Psychology, 102(1), 43-66.

Mutlu, M. and Sarı, M. (2017). Çok Kriterli Karar Verme Yöntemleri ve Madencilik Sektöründe Kullanımı. Bilimsel Madencilik Dergisi, 56(4), 181-196.

Ömürbek, N., Demirci, N. and Akalin, P. (2013). Analitik Ağ Süreci ve TOPSIS Yöntemleri ile Bilimdalı Seçimi. Akademik Araştırmalar ve Çalışmalar Dergisi, 5(9), 118-140.

Özçelik, H. and Kandemir, B. (2015). BIST'de İşlem Gören Turizm İşletmelerinin TOPSIS Yöntemi ile Finansal Performanslarının Değerlendirilmesi. Balıkesir Üniversitesi Sosyal Bilimler Enstitüsü Dergisi, 18(33), 97-114.

Ployhart, E. R., Schmitt, N. and Tippins, T. N. (2017). Solving the Supreme Problem: 100 Years of Selection and Recruitment at The Journal of Applied Psychology. Journal of Applied Psychology, 102(3), 291-304.

Supçiller, A. A. and Çapraz, O. (2011). AHP-TOPSIS Yöntemine Dayalı Tedarikçi Seçimi Uygulaması. Istanbul Üniversitesi iktisat Fakültesi Ekonometri ve İstatistik Dergisi, 13, 1-22.

Şenel, B., Şenel, M. and Aydemir, G. (2017). Çok Kriterli Karar Verme Metodu TOPSIS ile Personel Seçimi. Uluslararası Hakemli Ekonomi Yönetimi Araştırmaları Dergisi, 4(13), 19-70.

Ulutaş, Alptekin, Özkan, Ahmet Murat and Tağraf, Hasan (2018). Bulanık Analitik Hiyerarşi Süreci ve Bulanık Gri İlişkisel Analizi Yöntemleri Kullanılarak Personel Seçimi Yapılması. Elektronik Sosyal Bilimler Dergisi, 17(65), 223-232.

Urfalıoğlu, F. and Genç, T. (2013). Çok Kriterli Karar Verme Teknikleri ile Türkiye'nin Ekonomik Performansının Avrupa Birliği Üye Ülkeleri ile Karşılaştırılması. Maramara Üniversitesi iiBF Dergisi, 35(2), 329-360.

Uygurtürk, H. and Korkmaz, T. (2012). Finansal Performansın TOPSIS Çok Kriterli Karar Verme Yöntemi ile Belirlenmesi: Ana Metal Sanayi İşletmeleri Üzerine Bir Uygulama. Eskişehir Osmangazi Üniversitesi iiBF Dergisi, 7(2), 95-115.

Uzun, S. and Kazan, H. (2016). Çok Kriterli Karar Verme Yöntemlerinden AHP TOPSIS ve PROMETHEE Karşılaştırılması: Gemi İnşada Ana Makine Seçimi Uygulaması. Journal of Transportation and Logistics, 1(1), 99-113.

Ünal, Ömer Faruk (2011). Analitik Hiyerarşi Prosesi ve Personel Seçimi Alanında Uygulamaları, $A k$ deniz Üniversitesi Uluslararası Alanya İşletme Fakültesi Dergisi, 3(2), 18-38.

Yıldız, M.S. and Aksoy, S. (2015). Analitik Hiyerarşi Prosesi İle Personel Seçimi Üzerine Bir Çalışma. АівÜ Sosyal Bilimler Enstitüsü Dergisi, 15(1), 59-83. 
